Supporting Information for:

\title{
Symmetric Phthalocyanine Charge Carrier for Dual Redox- Flow Battery/Capacitor Applications
}

Camden Hunt, Maxwell Mattejat, Cassidy Anderson, Lior Sepunaru,* and Gabriel Ménard*

Department of Chemistry and Biochemistry, University of California, Santa Barbara, California 93106, United States

menard@chem.ucsb.edu; sepunaru@chem.ucsb.edu

\section{$\underline{\text { Table of Contents }}$}

S1. Methods S2-S3

S2. Electrochemistry

S4-S22

S3. References

S23 


\section{S1. Methods}

Techniques and Reagents. All manipulations were performed under an atmosphere of dry, oxygen-free $\mathrm{N}_{2}$ within an MBraun glovebox (MBRAUN UNIlab Pro SP Eco equipped with a $-40{ }^{\circ} \mathrm{C}$ freezer), or under an atmosphere of dry, oxygen-free Ar within a retrofitted VAC glovebox, or by standard Schlenk techniques. Pentane, $\mathrm{C}_{6} \mathrm{D}_{6}, \mathrm{Et}_{2} \mathrm{O}, \mathrm{DCM}$ and THF (inhibitor-free) were dried and degassed on an MBraun Solvent Purification System and stored over activated $4 \AA$ molecular sieves. All other solvents were degassed by freeze-pump-thaw and stored on activated $4 \AA$ molecular sieves prior to use. Celite $\AA$ and $4 \AA$ molecular sieves were dried at $250{ }^{\circ} \mathrm{C}$ under dynamic vacuum $(<0.1$ Torr) for $24 \mathrm{~h}$ prior to use. Compound 1 was prepared by previously reported methods. ${ }^{1}$ Ketjenblack® EC-600JD (KB) was purchased from a private supplier. All other reagents were obtained from Sigma-Aldrich, Fisher Scientific, or VWR and used without further purification.

Electrochemical Measurements. Cyclic voltammograms were performed on a $\mathrm{CH}$ Instruments 630E Electrochemical Analysis Potentiostat. All working electrodes were of $3.0 \mathrm{~mm}$ diameter (CH Instruments) and were cleaned prior to each experiment by sequentially polishing with a gradient of $1.0 \mu \mathrm{m}, 0.3 \mu \mathrm{m}$, and $0.05 \mu \mathrm{m}$ alumina ( $\mathrm{CH}$ Instruments) on a cloth pad, followed by rinsing with distilled water and acetone. The Pt wire pseudoreference and counter electrodes were rinsed with distilled water and acetone and heated white-hot with a butane torch. All measurements were performed on recrystallized product and referenced to the $\mathrm{Fc} / \mathrm{Fc}^{+}$redox couple unless otherwise stated. Static cell cycling experiments were carried out using a Metrohm Autolab PGSTAT128N potentiostat/galvanostat, utilizing voltage cutoffs. For cycling experiments, two coiled Pt electrodes (Bio-Logic) were used and were cleaned by rinsing with distilled water and acetone and then heating white-hot with a butane torch. All electrodes were transferred into a glovebox and subsequently rinsed with the respective electrolyte solution immediately prior to use. The $\mathrm{H}-$ cell was custom-made by the in-house glassblower. All electrochemical measurements were performed under an inert atmosphere. For slurry measurements, solid material was first ground together using a mortar and pestle, and then combined with $5 \mathrm{~mL}$ of $0.2 \mathrm{M}\left[\mathrm{Bu}_{4} \mathrm{~N}\right]\left[\mathrm{PF}_{6}\right]$ in $\mathrm{CH}_{3} \mathrm{CN}$, and sonicated for $1 \mathrm{~h}$ prior to addition to the $\mathrm{H}$-cell. For all cycling efficiency metrics, the first cycle was discarded.

Faradaic efficiency $(F E)$ was defined by Eq. 1:

(1) $F E=\frac{Q_{\text {discharge }}}{Q_{\text {charge }}} * 100 \%$

Where $Q$ is charge transferred. Voltage efficiency (VE) was defined by Eq. 2:

(2) $V E=\frac{V(\text { mean })_{\text {discharge }}}{V(\text { mean })_{\text {charge }}} * 100 \%$

Where $V_{(\text {mean })}$ is the mean voltage. Energy efficiency $(E E)$ was defined by Eq. 3:

(3) $E E=\frac{(F E \times V E)}{100 \%}$

DigiSim simulations. All simulations were performed with the same concentration, starting potential, ending potential, voltage window, experimental $E^{\circ}$, and scan rate as experimental, and the assumption that $\mathrm{T}=298 \mathrm{~K}, \mathrm{r}=1.5 \mathrm{~mm}$. All events were assumed to have an $\alpha / \lambda$ ratio of 0.5 , and the diffusion coefficient $(D)$ and the heterogeneous charge transfer constant $\left(k_{0}\right)$ were fitted to all scan rates to produce the closest fits. 


\section{Energy density calculations.}

The energy density was calculated using the following assumptions:

1) $\mathrm{KB}$ provides $2.5 \mathrm{C}$ when $100 \mathrm{mg}$ is used (estimated from experimental charge/discharge curves; Figure S9)

2) 1 provides $2 \mathrm{e}^{-}$per molecule, and has a molecular weight of $934 \mathrm{~g} / \mathrm{mol}$

3) Experimental $V_{\text {cell }}($ discharge) values were used for each calculation

\section{Solution-state cycling:}

Using the following equation ${ }^{2}: \quad \hat{E}_{R F B}=0.5 n \cdot V_{\text {cell }} \bullet C_{\text {active }} \bullet F$

where: $\quad \hat{E}_{R F B}=$ energy density for RFB

$n=$ number of electrons transferred at the electrodes $=2$

$V_{\text {cell }}=$ cell potential

$C_{\text {active }}=$ concentration of the redox active species

$F=$ Faraday's constant $=96,485 \mathrm{C} / \mathrm{mol}$

with: $\quad 4.7 \mathrm{mg}$ of $\mathbf{1}$ dissolved in $10 \mathrm{~mL}$

$V_{\text {cell }}=1.40 \mathrm{~V}$

then: $\quad \hat{E}_{R F B}=0.5 \times 2 \times 1.4 \mathrm{~V} \times\left(\frac{0.0047 \mathrm{~g} / 934 \mathrm{~g} / \mathrm{mol}}{0.010 \mathrm{~L}}\right) \times 96,485 \mathrm{C} / \mathrm{mol}=67.9 \mathrm{~J} / \mathrm{L} \approx 0.02 \mathrm{Wh} / \mathrm{L}$

\section{KB cycling:}

Using the following equation: $\quad \hat{E}_{E F C}=\frac{q \times V_{\text {cell }}}{\text { volume }}$

where: $\hat{E}_{E F C}=$ energy density for EFC

$q=$ total charge transferred $=2.5 \mathrm{C}$ (using $100 \mathrm{mg} \mathrm{KB}$ and following assumption 1 above) volume $=0.010 \mathrm{~L}$

with: $\quad V_{\text {cell }}=0.84 \mathrm{~V}$

then: $\quad \hat{E}_{E F C}=\frac{2.5 \mathrm{C} \times 0.84 \mathrm{~V}}{0.010 \mathrm{~L}}=210 \mathrm{~J} / \mathrm{L} \approx 0.06 \mathrm{Wh} / \mathrm{L}$

\section{Slurry-state cycling:}

Using the following equation: $\quad \hat{E}_{\text {total }}=\hat{E}_{R F B}+\hat{E}_{E F C}$

with: $\quad 130 \mathrm{mg}$ of $\mathbf{1}$

$210 \mathrm{mg}$ of $\mathrm{KB}$

volume $=0.010 \mathrm{~L}$

$V_{\text {cell }}=1.04 \mathrm{~V}$ 
then:

$$
\begin{aligned}
\hat{\mathrm{E}}_{\text {total }}=[0.5 \times & \left.2 \times 1.04 \mathrm{~V} \times \frac{0.130 \mathrm{~g} / \mathrm{934 \textrm {g } / \mathrm { mol }}}{0.010 \mathrm{~L}} \times 96,485 \mathrm{C} / \mathrm{mol}\right] \\
& +\left[\frac{(210 \mathrm{mg} \times 2.5 \mathrm{C} / 100 \mathrm{mg}) \times 1.04 \mathrm{~V}}{0.010 \mathrm{~L}}\right]=1943 \mathrm{~J} / \mathrm{L} \approx 0.54 \mathrm{Wh} / \mathrm{L}
\end{aligned}
$$

S2. Electrochemistry

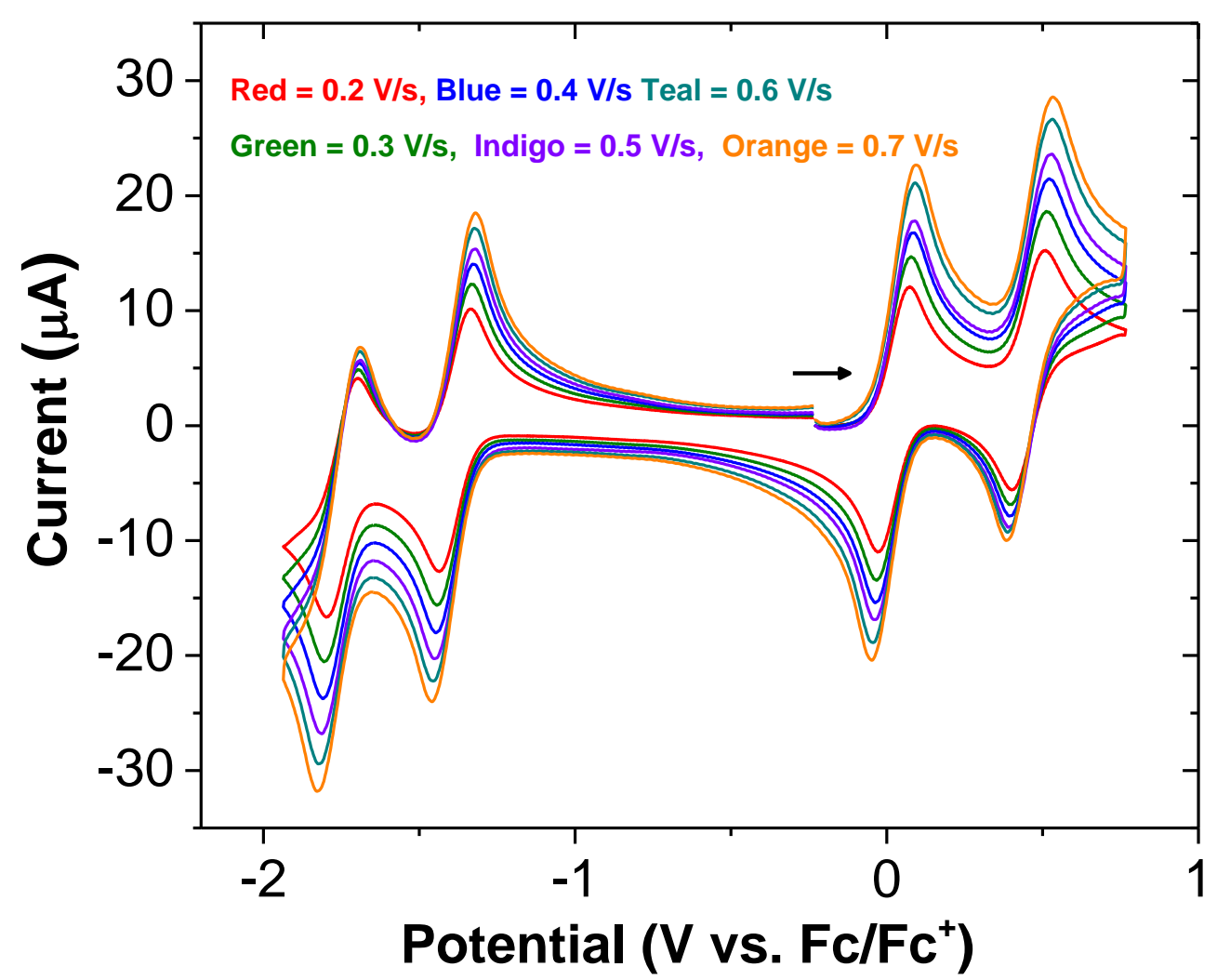

Figure S1. CV of 1 at varying scan rates (inset). Experimental conditions: Taken in DCM with $0.29 \mathrm{mM}$ of $1,0.1 \mathrm{M}$ of $\left[\mathrm{Bu}_{4} \mathrm{~N}\right]\left[\mathrm{PF}_{6}\right], 3 \mathrm{~mm}$ diameter glassy carbon working electrode, Pt wire counter electrode, and Pt wire pseudoreference electrode. 


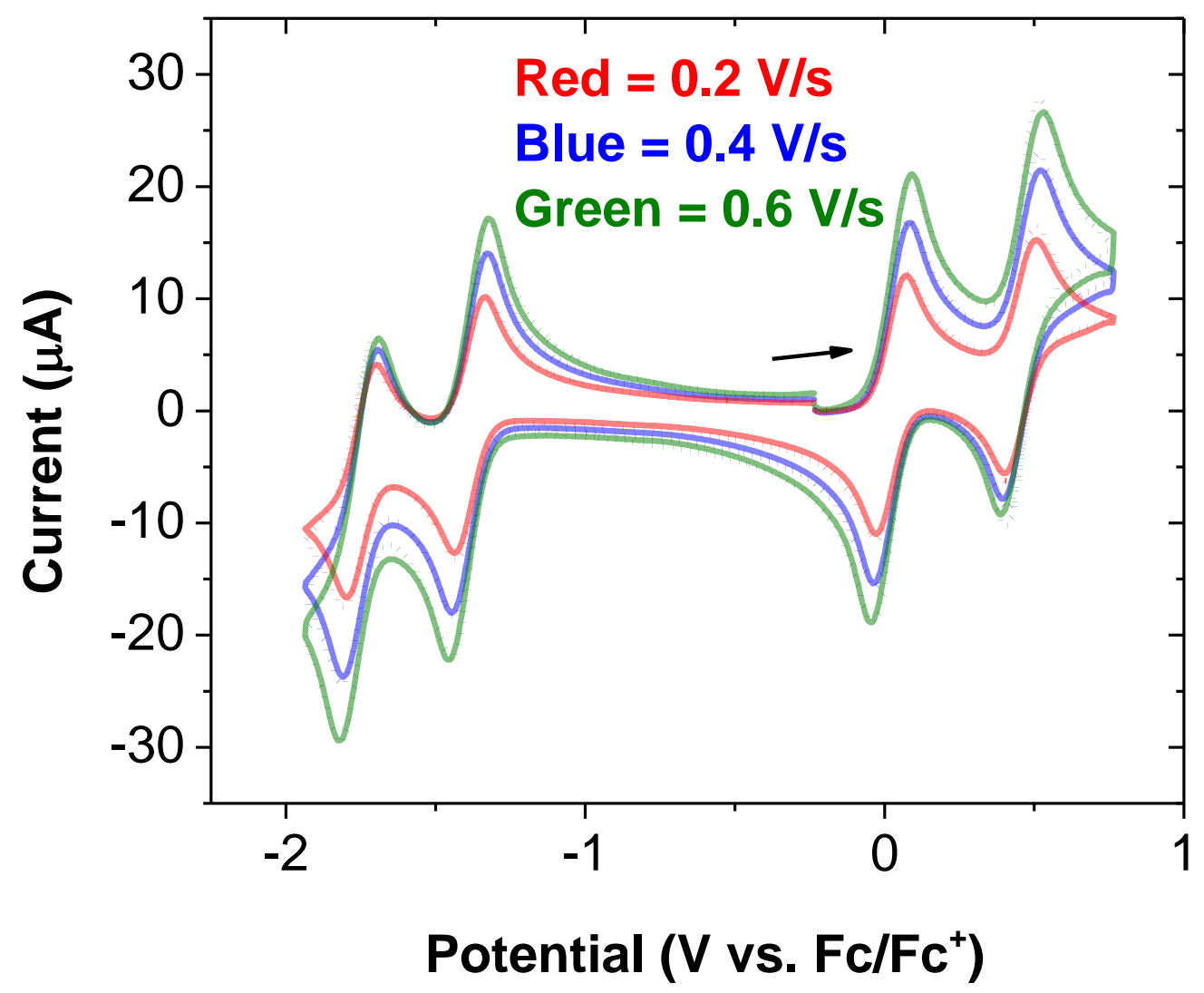

Figure S2. CV of $\mathbf{1}$ at varying scan rates (solid lines) and DigiSim fit of experimental results (dotted lines). Experimental conditions: Taken in DCM with $0.29 \mathrm{mM}$ of $1,0.1 \mathrm{M}$ of $\left[\mathrm{Bu}_{4} \mathrm{~N}\right]\left[\mathrm{PF}_{6}\right]$, $3 \mathrm{~mm}$ diameter glassy carbon working electrode, Pt wire counter electrode, and $\mathrm{Pt}$ wire pseudoreference electrode. 


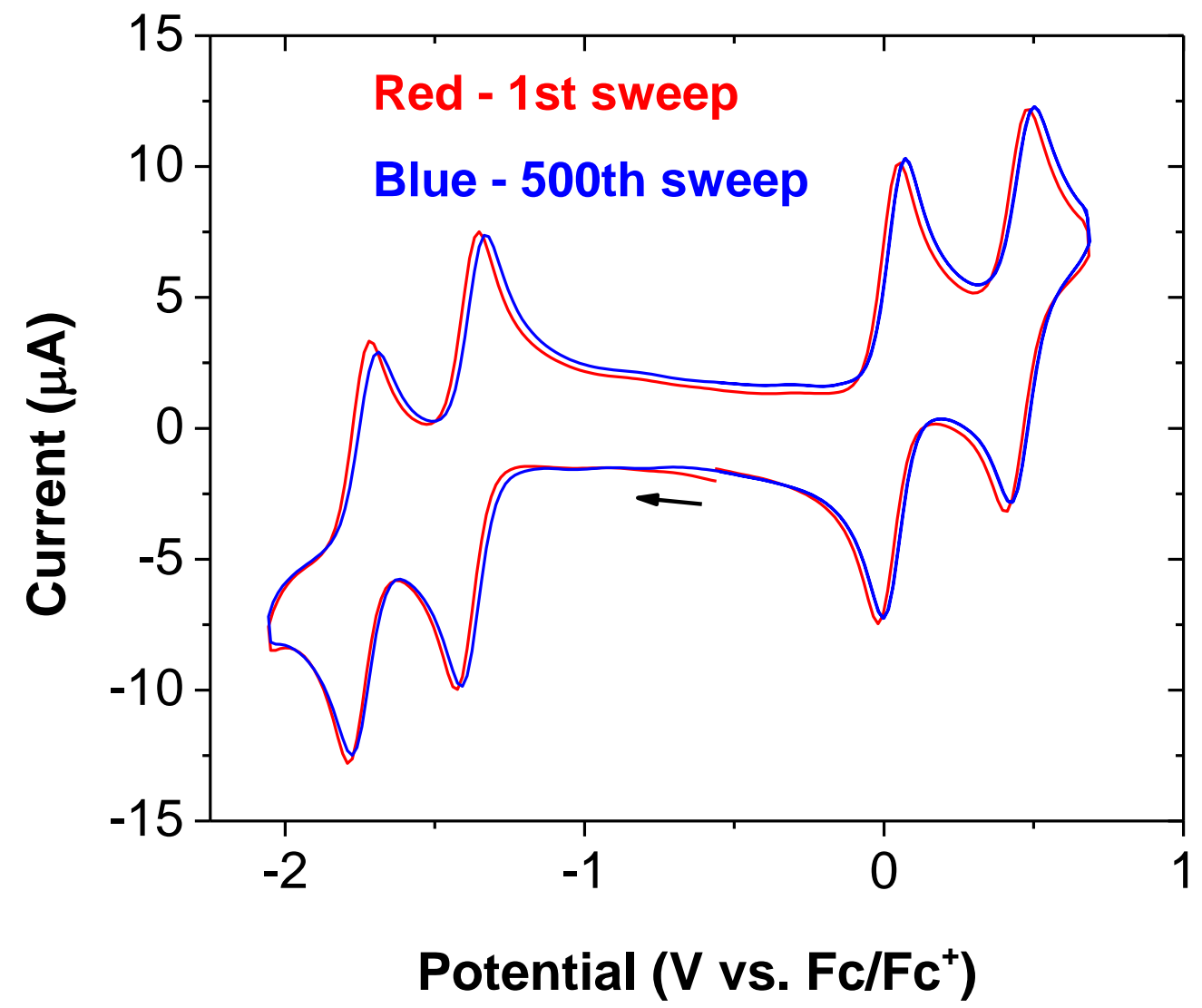

Figure S3. Multi-sweep CV of 1 displaying first scan (red) and $500^{\text {th }}$ scan (blue). Experimental conditions: taken in DCM with $0.24 \mathrm{mM}$ of $1,0.1 \mathrm{M}$ of $\left[\mathrm{Bu}_{4} \mathrm{~N}\right]\left[\mathrm{PF}_{6}\right], 3 \mathrm{~mm}$ diameter glassy carbon working electrode, Pt wire counter electrode, and Pt wire pseudoreference electrode, scan rate 500 $\mathrm{mV} / \mathrm{s}$. 


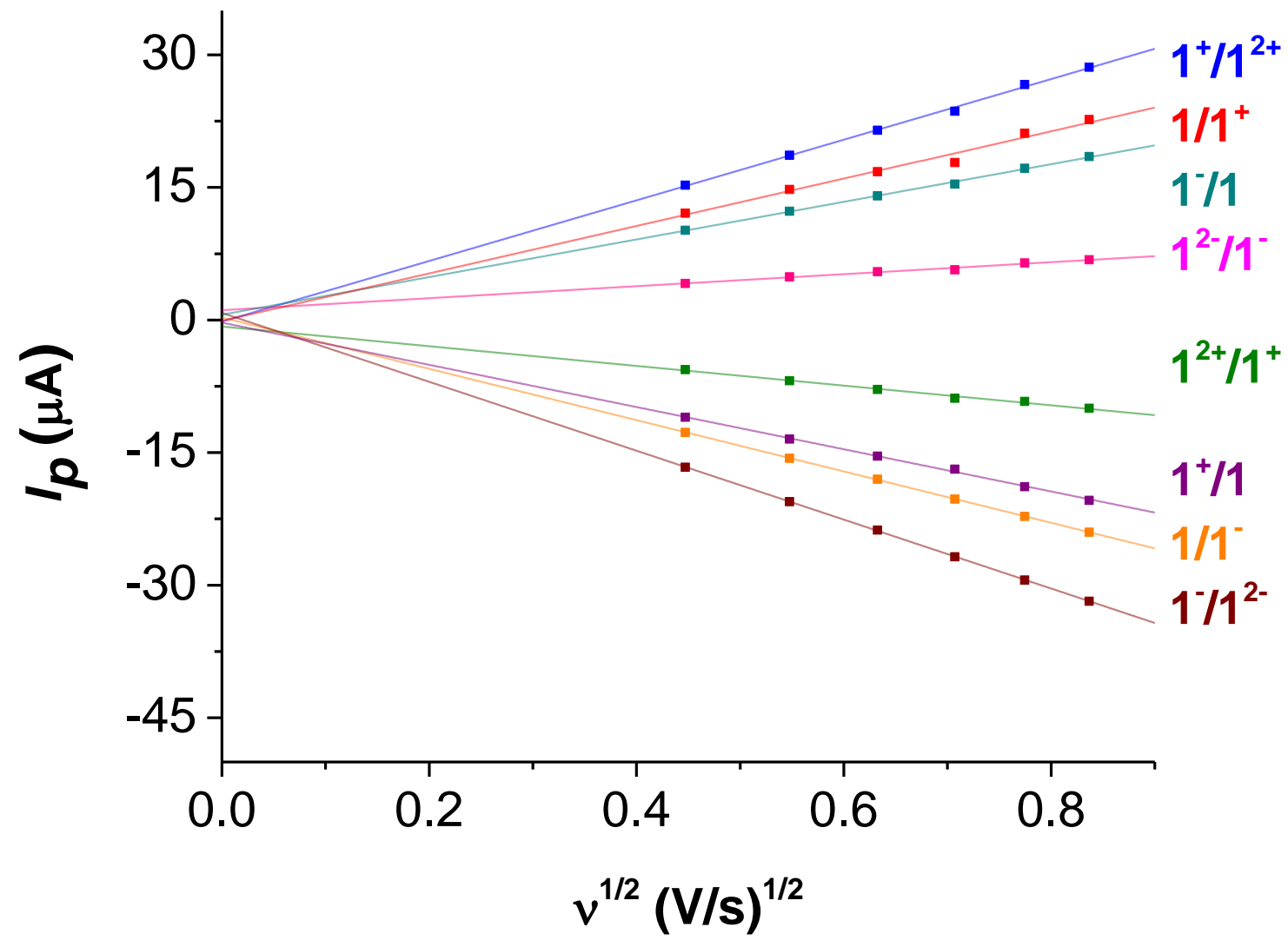

Figure S4. Randles-Ševčík plot for 1 in DCM.

Table S1. Slope and $\mathrm{R}^{2}$ values obtained from the Randles-Ševčík analysis.

\begin{tabular}{ccc} 
Redox Event & Slope & $\mathbf{R}^{\mathbf{2}}$ \\
\hline $\mathbf{1}^{+} \mathbf{1}^{+}$ & $2.68 \cdot 10^{-5}$ & 0.98 \\
$\mathbf{1}^{+} / \mathbf{1}^{\mathbf{2 +}}$ & $3.43 \cdot 10^{-5}$ & 0.99 \\
$\mathbf{1}^{\mathbf{2}} / \mathbf{1}^{+}$ & $-1.12 \cdot 10^{-5}$ & 0.99 \\
$\mathbf{1}^{+/ 1}$ & $-2.39 \cdot 10^{-5}$ & 0.99 \\
$\mathbf{1}^{-}$ & $-2.90 \cdot 10^{-5}$ & 0.99 \\
$\mathbf{1}^{-} / \mathbf{1}^{2-}$ & $-3.90 \cdot 10^{-5}$ & 0.99 \\
$\mathbf{1}^{\mathbf{-}} / \mathbf{1}^{-}$ & $6.79 \cdot 10^{-6}$ & 0.98 \\
$\mathbf{1}^{-/ 1}$ & $2.13 \cdot 10^{-5}$ & 0.99
\end{tabular}




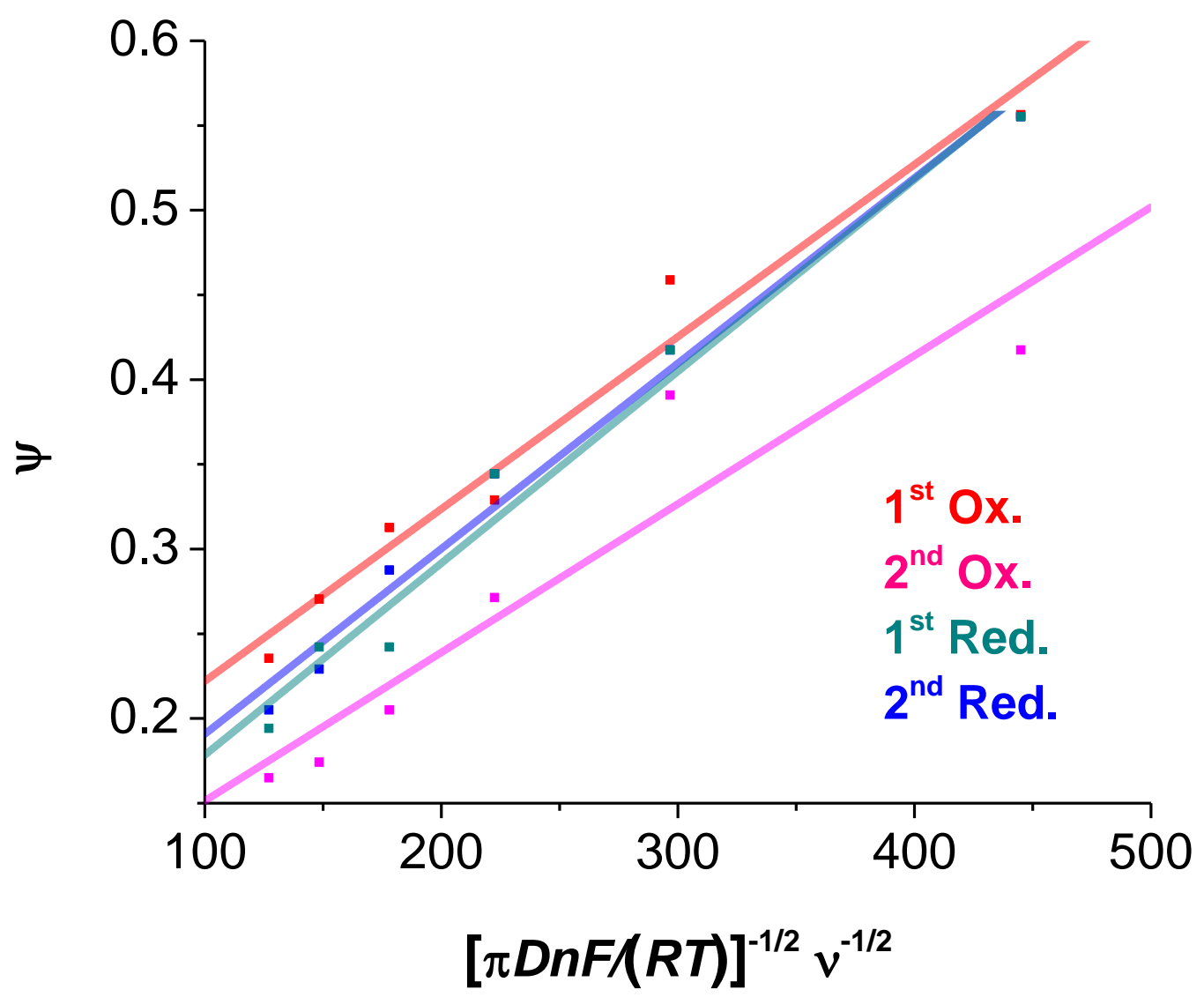

Figure S5. Nicholson plot for $\mathbf{1}$ in DCM.

Table S2. Slope and $\mathrm{R}^{2}$ values obtained from the Nicholson analysis.

\begin{tabular}{ccc} 
Redox Event & Slope & $\mathbf{R}^{\mathbf{2}}$ \\
\hline \hline $\mathbf{1} / \mathbf{1}^{+}$ & 0.0010 & 0.962 \\
$\mathbf{1}^{+/ \mathbf{1}^{\mathbf{+}}}$ & 0.0009 & 0.863 \\
$\mathbf{1 / 1}^{-}$ & 0.0011 & 0.971 \\
$\mathbf{1}^{-/ \mathbf{1}^{-}}$ & 0.0011 & 0.981
\end{tabular}




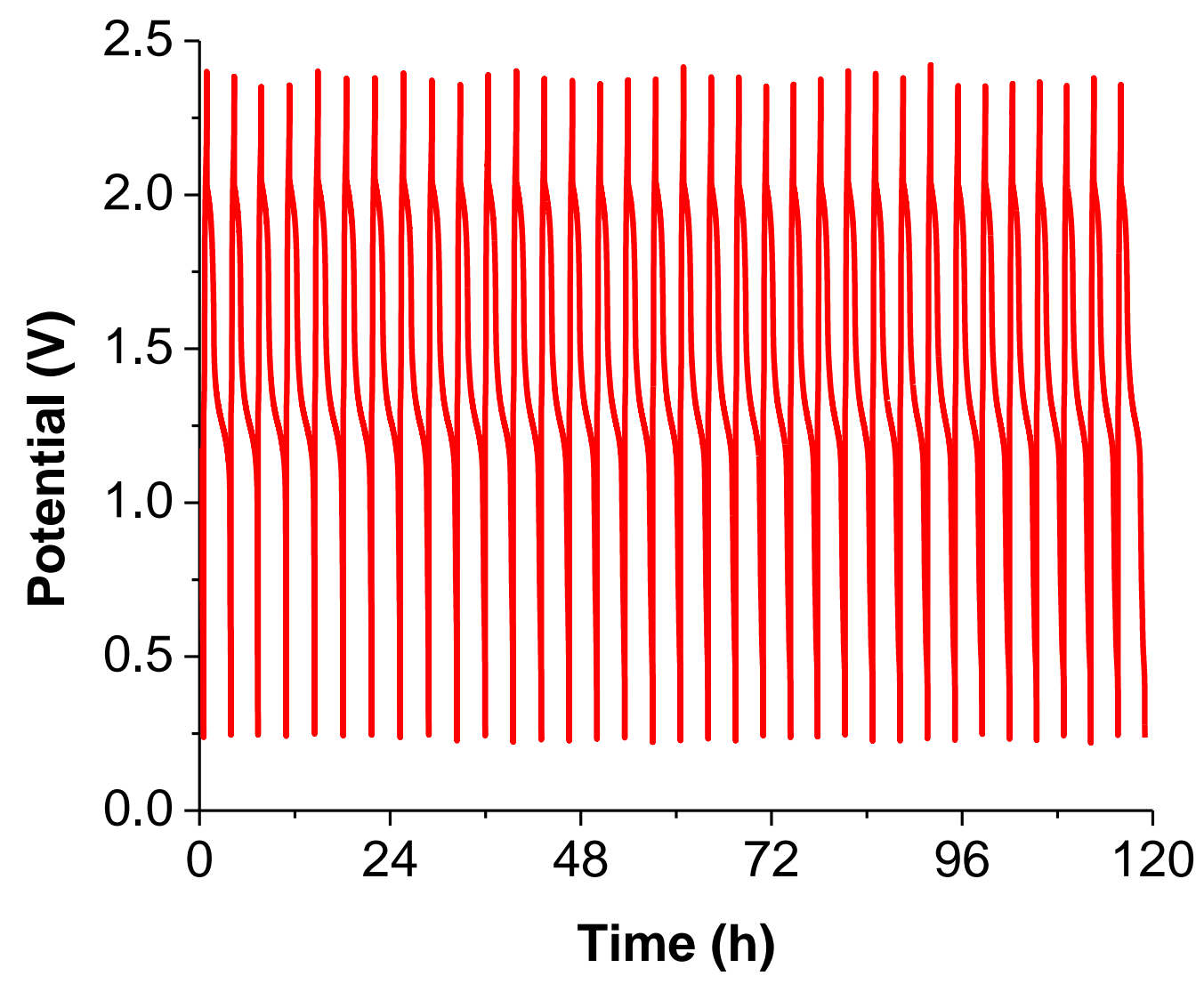

Figure S6. Galvanostatic, two-electrode charge-discharge curves of $\mathbf{1}$. Taken in a glass-fritted Hcell in $\mathrm{CH}_{3} \mathrm{CN}$ (5 mL per compartment; $10 \mathrm{~mL}$ total) with $\left[\mathrm{Bu}_{4} \mathrm{~N}\right]\left[\mathrm{PF}_{6}\right](0.2 \mathrm{M})$ and $\mathbf{1}(0.50 \mathrm{mM})$. Coiled Pt working electrode, coiled Pt counter electrode. $100 \mu \mathrm{A}$ charge, $-12.5 \mu \mathrm{A}$ discharge. 


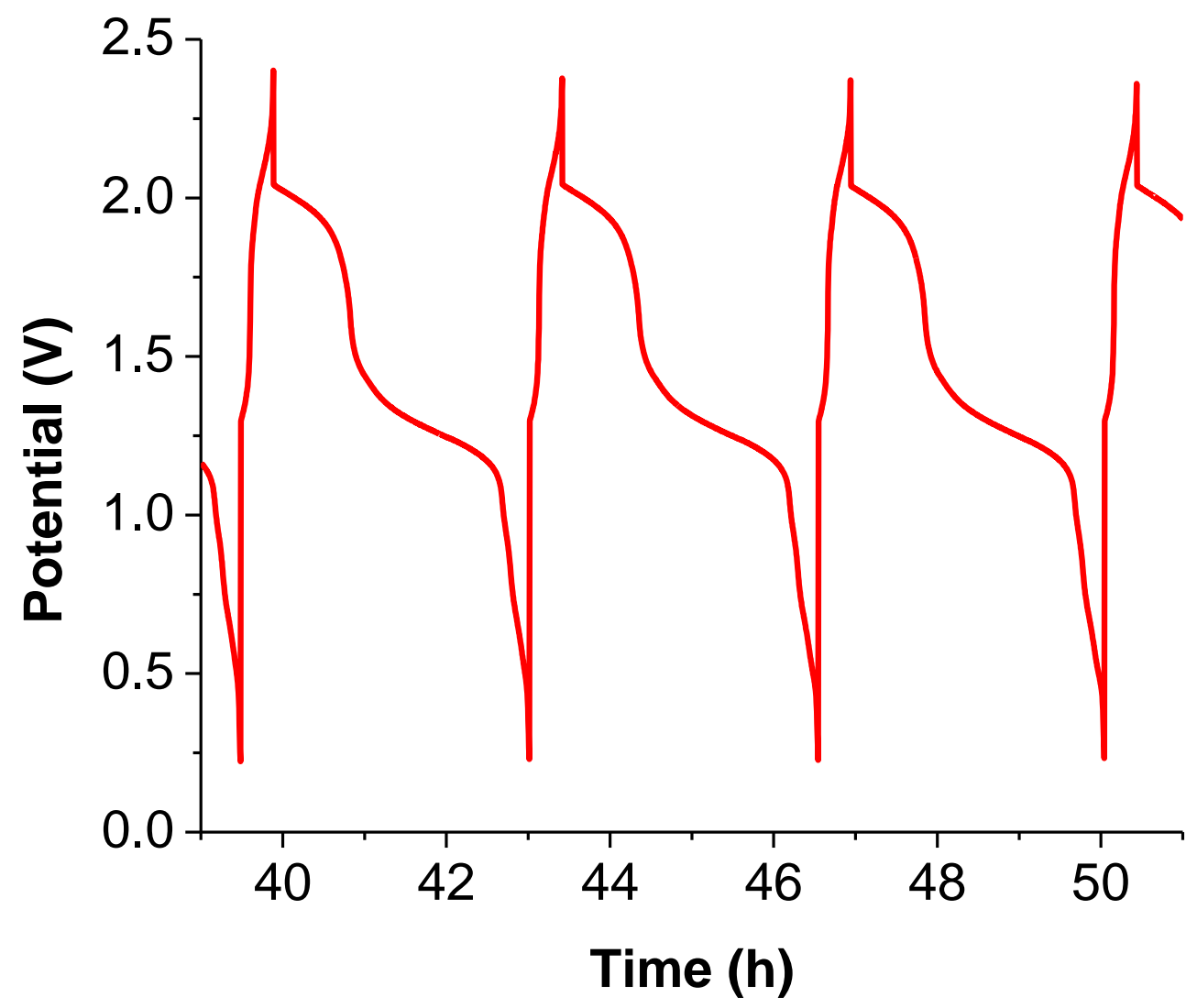

Figure S7. Selected galvanostatic charge-discharge curves for $\mathbf{1}$. Taken in a glass-fritted $\mathrm{H}$-cell in $\mathrm{CH}_{3} \mathrm{CN}\left(5 \mathrm{~mL}\right.$ per compartment; $10 \mathrm{~mL}$ total) with $\left[\mathrm{Bu}_{4} \mathrm{~N}\right]\left[\mathrm{PF}_{6}\right](0.2 \mathrm{M})$ and $1(0.50 \mathrm{mM})$. Coiled Pt working electrode, coiled Pt counter electrode. $100 \mu \mathrm{A}$ charge, $-12.5 \mu \mathrm{A}$ discharge. 


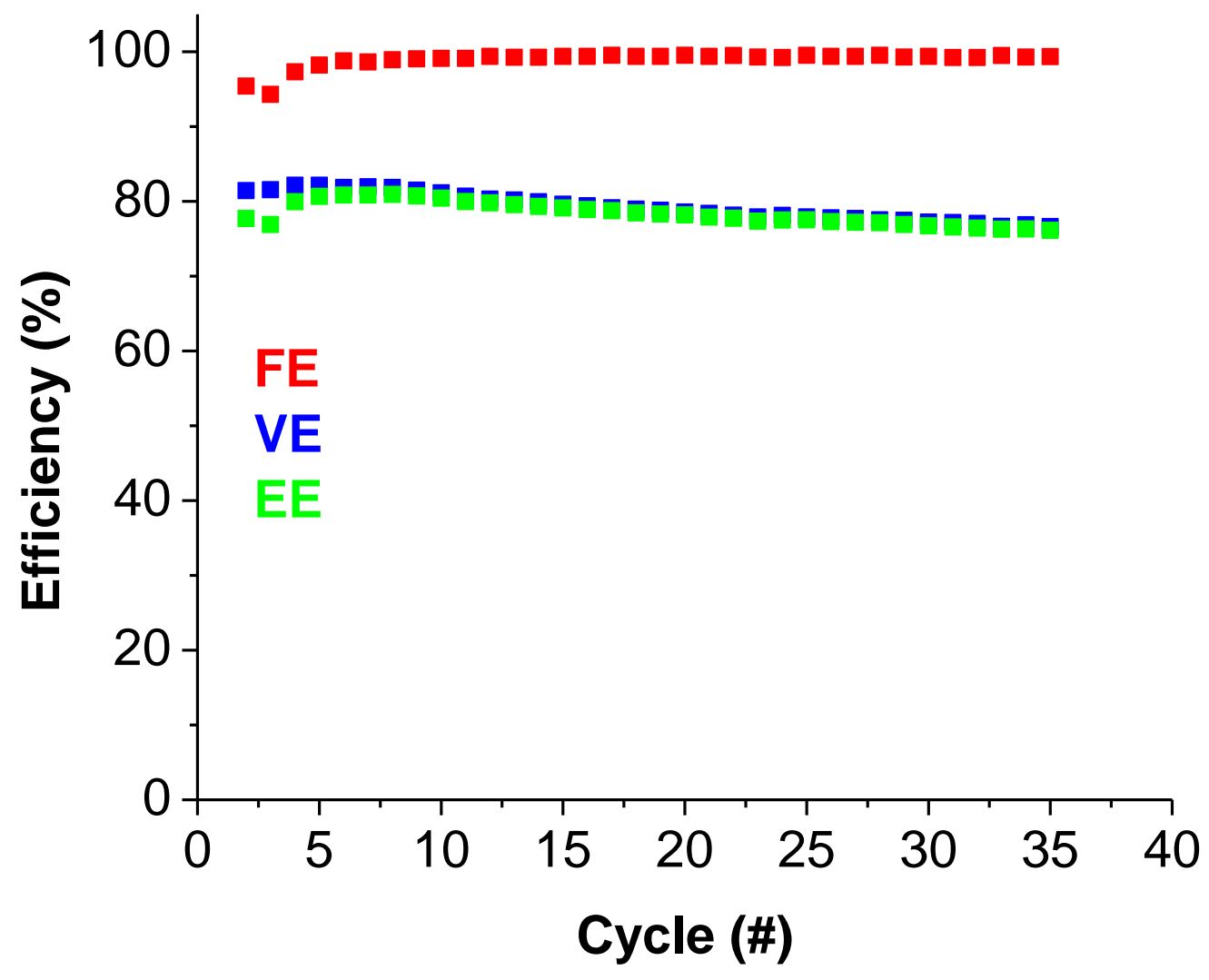

Figure S8. Efficiency values of 1 (Faradaic efficiency (FE); Voltage efficiency (VE); Energy efficiency (EE)). Taken in a glass-fritted $\mathrm{H}$-cell in $\mathrm{CH}_{3} \mathrm{CN}$ (5 mL per compartment; $10 \mathrm{~mL}$ total) with $\left[\mathrm{Bu}_{4} \mathrm{~N}\right]\left[\mathrm{PF}_{6}\right](0.2 \mathrm{M})$ and $\mathbf{1}(0.50 \mathrm{mM})$. Coiled Pt working electrode, coiled Pt counter electrode. $100 \mu \mathrm{A}$ charge, $-12.5 \mu \mathrm{A}$ discharge. 


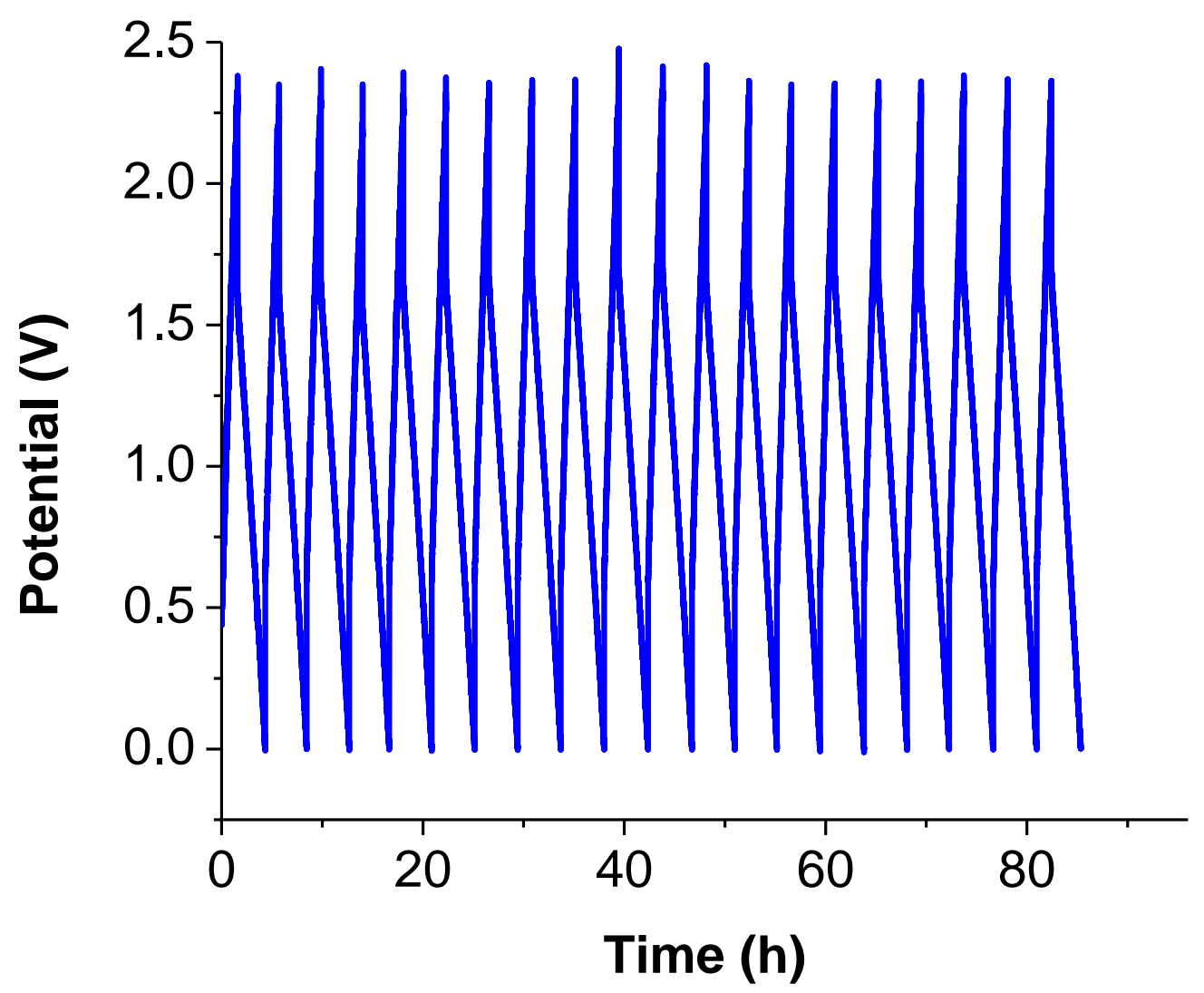

Figure S9. Galvanostatic, two-electrode charge-discharge curves of a slurry of KB. Taken in a glass-fritted $\mathrm{H}$-cell with $\mathrm{CH}_{3} \mathrm{CN}, 0.2 \mathrm{M}\left[\mathrm{Bu}_{4} \mathrm{~N}\right]\left[\mathrm{PF}_{6}\right], 50 \mathrm{mg}$ of $\mathrm{KB}$ per compartment, and $5 \mathrm{~mL}$ of solution per side. Coiled Pt working electrode, coiled Pt counter electrode. $500 \mu \mathrm{A}$ charge, -250 $\mu$ A discharge. 


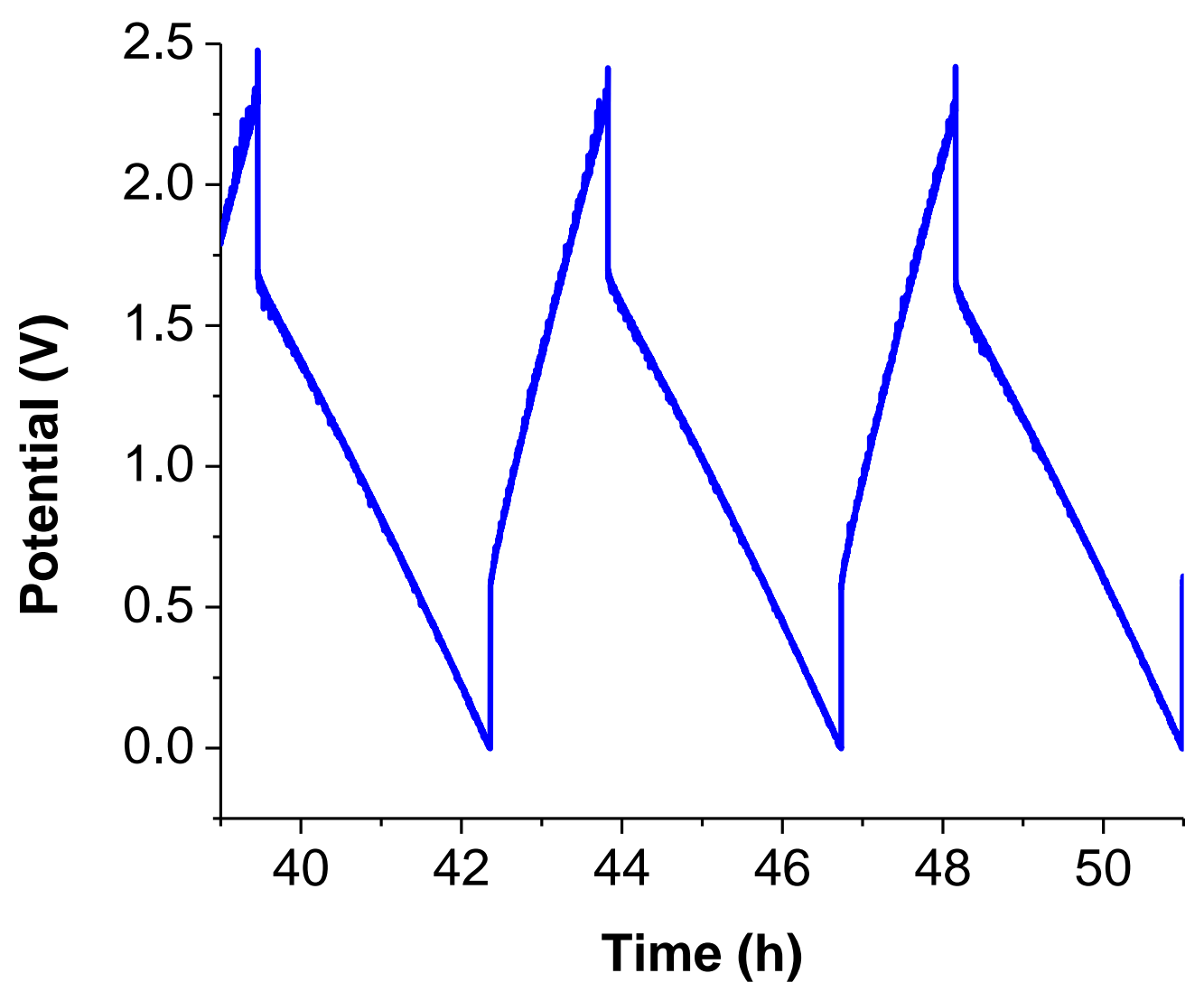

Figure S10. Galvanostatic, two-electrode charge-discharge curves of a slurry of KB. Taken in a glass-fritted $\mathrm{H}$-cell with $\mathrm{CH}_{3} \mathrm{CN}, 0.2 \mathrm{M}\left[\mathrm{Bu}_{4} \mathrm{~N}\right]\left[\mathrm{PF}_{6}\right], 50 \mathrm{mg}$ of $\mathrm{KB}$ per compartment, and $5 \mathrm{~mL}$ of solution per side. Coiled Pt working electrode, coiled Pt counter electrode. $500 \mu \mathrm{A}$ charge, -250 $\mu$ A discharge. 


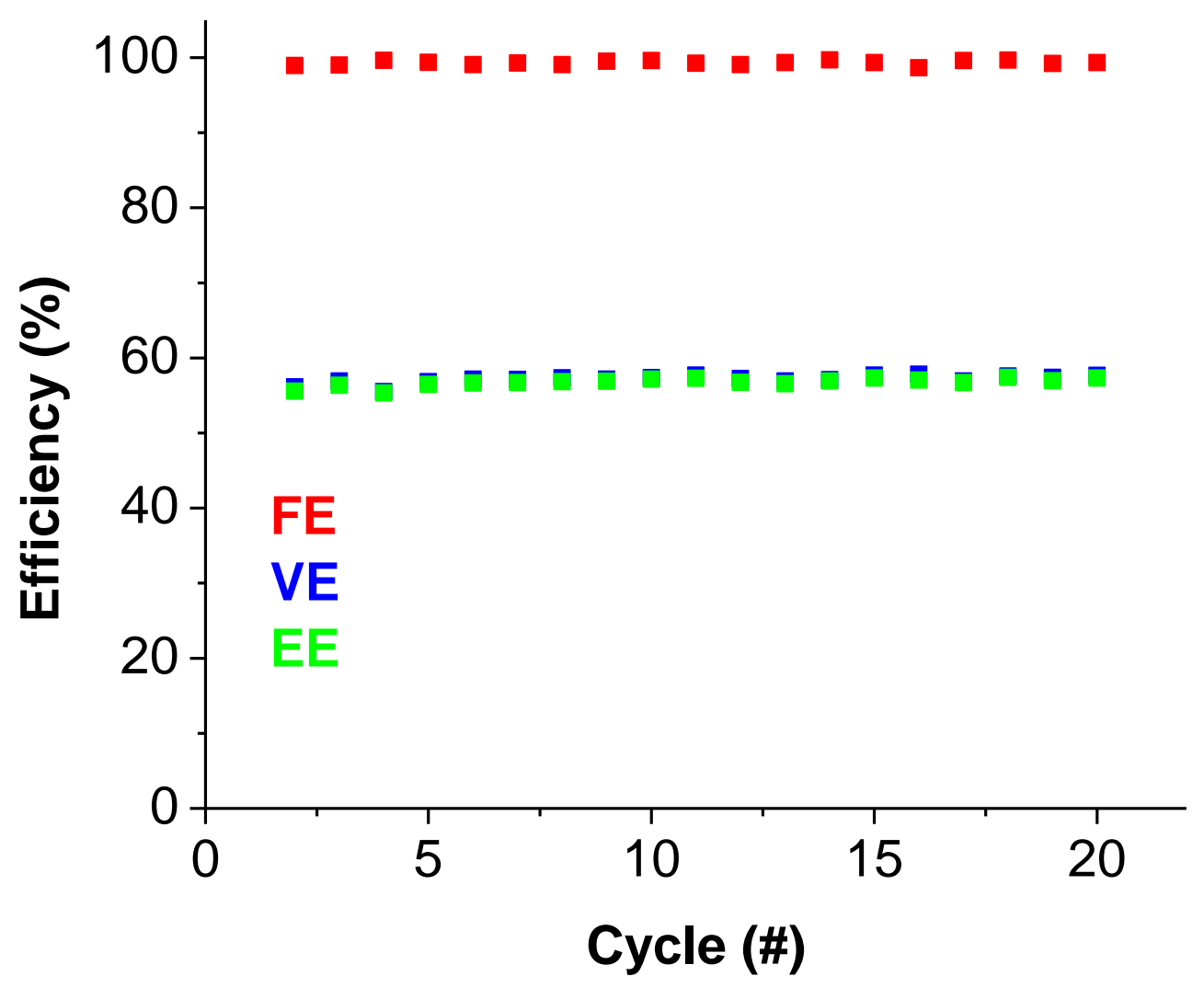

Figure S11. Efficiency values of a slurry of KB (Faradaic efficiency (FE); Voltage efficiency (VE); Energy efficiency (EE)). Taken in a glass-fritted $\mathrm{H}$-cell with $\mathrm{CH}_{3} \mathrm{CN}, 0.2 \mathrm{M}\left[\mathrm{Bu}_{4} \mathrm{~N}\right]\left[\mathrm{PF}_{6}\right]$, $50 \mathrm{mg}$ of $\mathrm{KB}$ per compartment, and $5 \mathrm{~mL}$ of solution per side. Coiled $\mathrm{Pt}$ working electrode, coiled Pt counter electrode. $500 \mu \mathrm{A}$ charge, $-250 \mu \mathrm{A}$ discharge. 


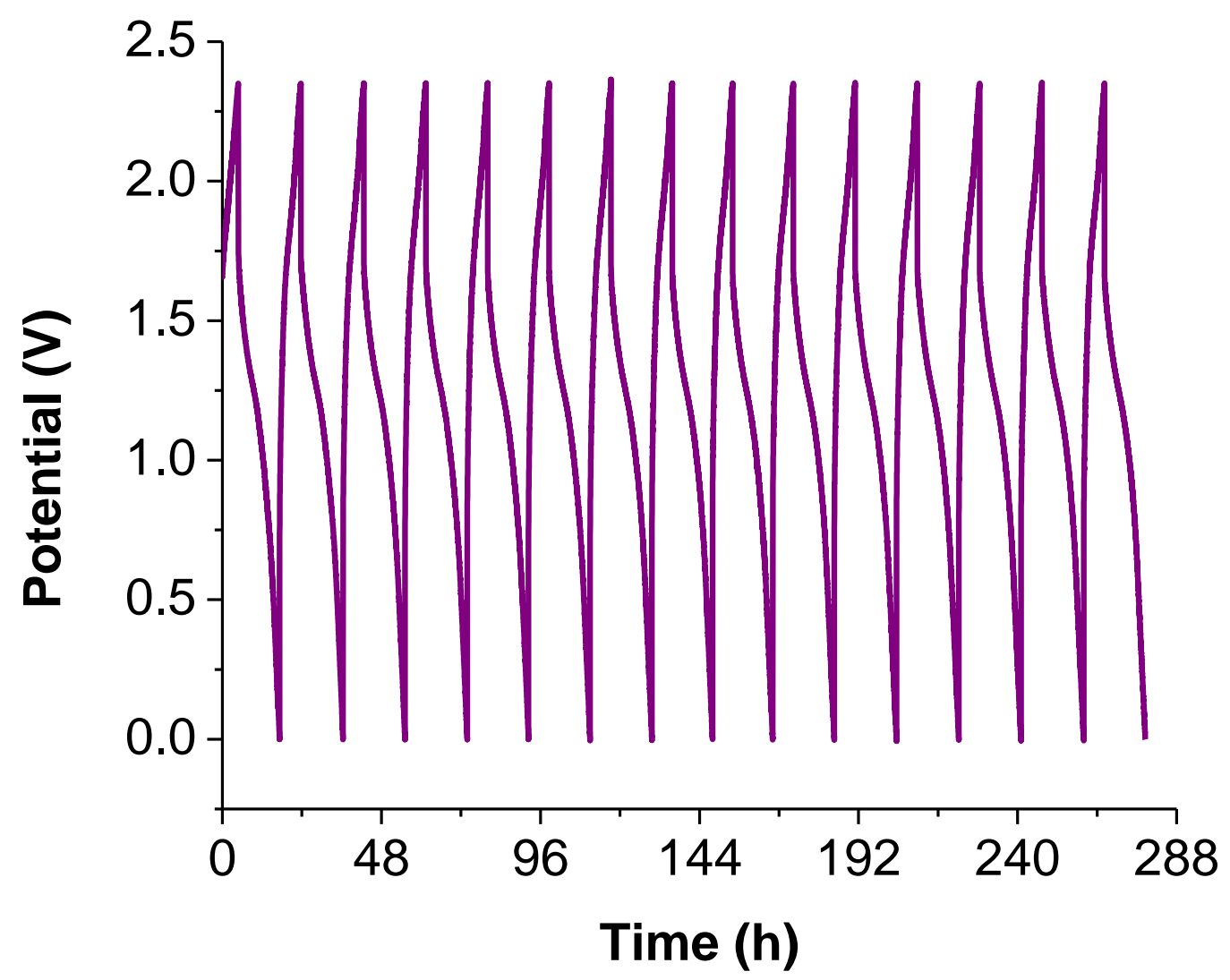

Figure S12. Galvanostatic, two-electrode charge-discharge curves of a slurry of $1 / \mathrm{KB}$. Taken in a glass-fritted $\mathrm{H}$-cell with $\mathrm{CH}_{3} \mathrm{CN}, 0.2 \mathrm{M}\left[\mathrm{Bu}_{4} \mathrm{~N}\right]\left[\mathrm{PF}_{6}\right], 65 \mathrm{mg}$ of 1 and $105 \mathrm{mg}$ of $\mathrm{KB}$ per compartment, and $5 \mathrm{~mL}$ of solution per side. Coiled Pt working electrode, coiled Pt counter electrode. $500 \mu \mathrm{A}$ charge, $-250 \mu \mathrm{A}$ discharge. 


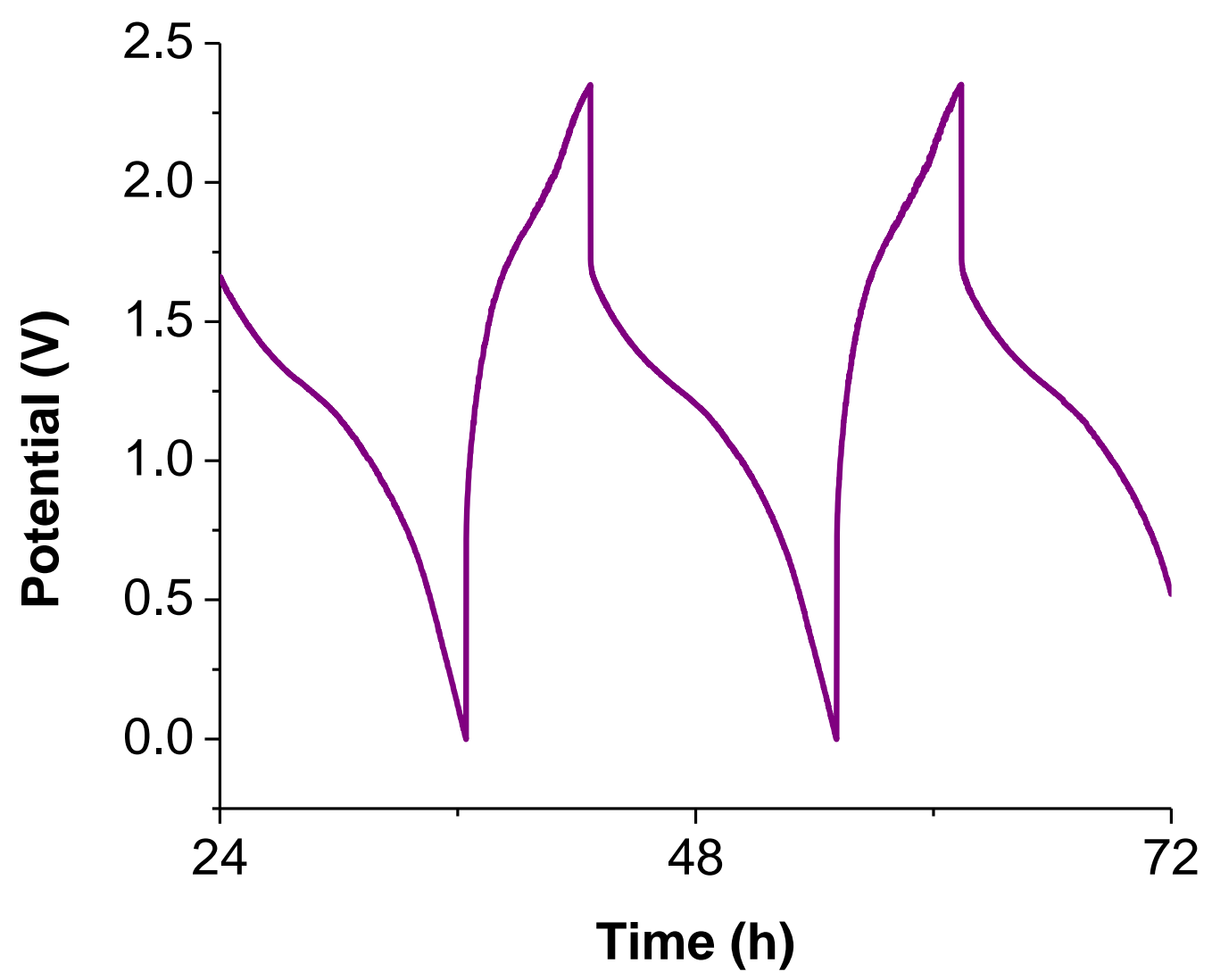

Figure S13. Galvanostatic, two-electrode charge-discharge curves of a slurry of $1 / K B$. Taken in a glass-fritted $\mathrm{H}$-cell with $\mathrm{CH}_{3} \mathrm{CN}, 0.2 \mathrm{M}\left[\mathrm{Bu}_{4} \mathrm{~N}\right]\left[\mathrm{PF}_{6}\right], 65 \mathrm{mg}$ of 1 and $105 \mathrm{mg}$ of $\mathrm{KB}$ per compartment, and $5 \mathrm{~mL}$ of solution per side. Coiled Pt working electrode, coiled Pt counter electrode. $500 \mu \mathrm{A}$ charge, $-250 \mu \mathrm{A}$ discharge. 


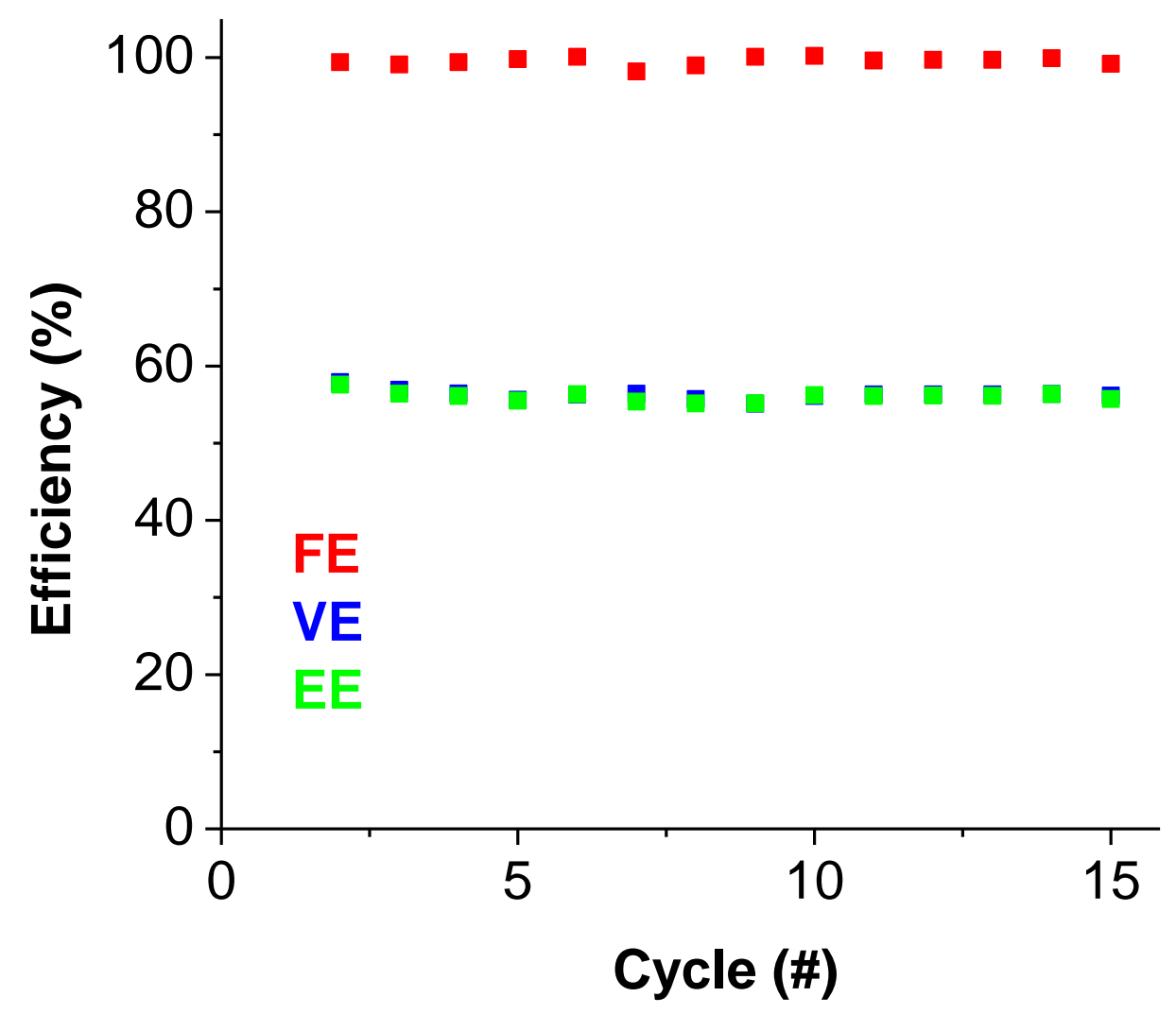

Figure S14. Efficiency values of a slurry of 1/KB (Faradaic efficiency (FE); Voltage efficiency (VE); Energy efficiency (EE)). Taken in a glass-fritted $\mathrm{H}$-cell with $\mathrm{CH}_{3} \mathrm{CN}, 0.2 \mathrm{M}\left[\mathrm{Bu}_{4} \mathrm{~N}\right]\left[\mathrm{PF}_{6}\right]$, $65 \mathrm{mg}$ of 1 and $105 \mathrm{mg}$ of $\mathrm{KB}$ per compartment, and $5 \mathrm{~mL}$ of solution per side. Coiled Pt working electrode, coiled Pt counter electrode. $500 \mu \mathrm{A}$ charge, $-250 \mu \mathrm{A}$ discharge. 


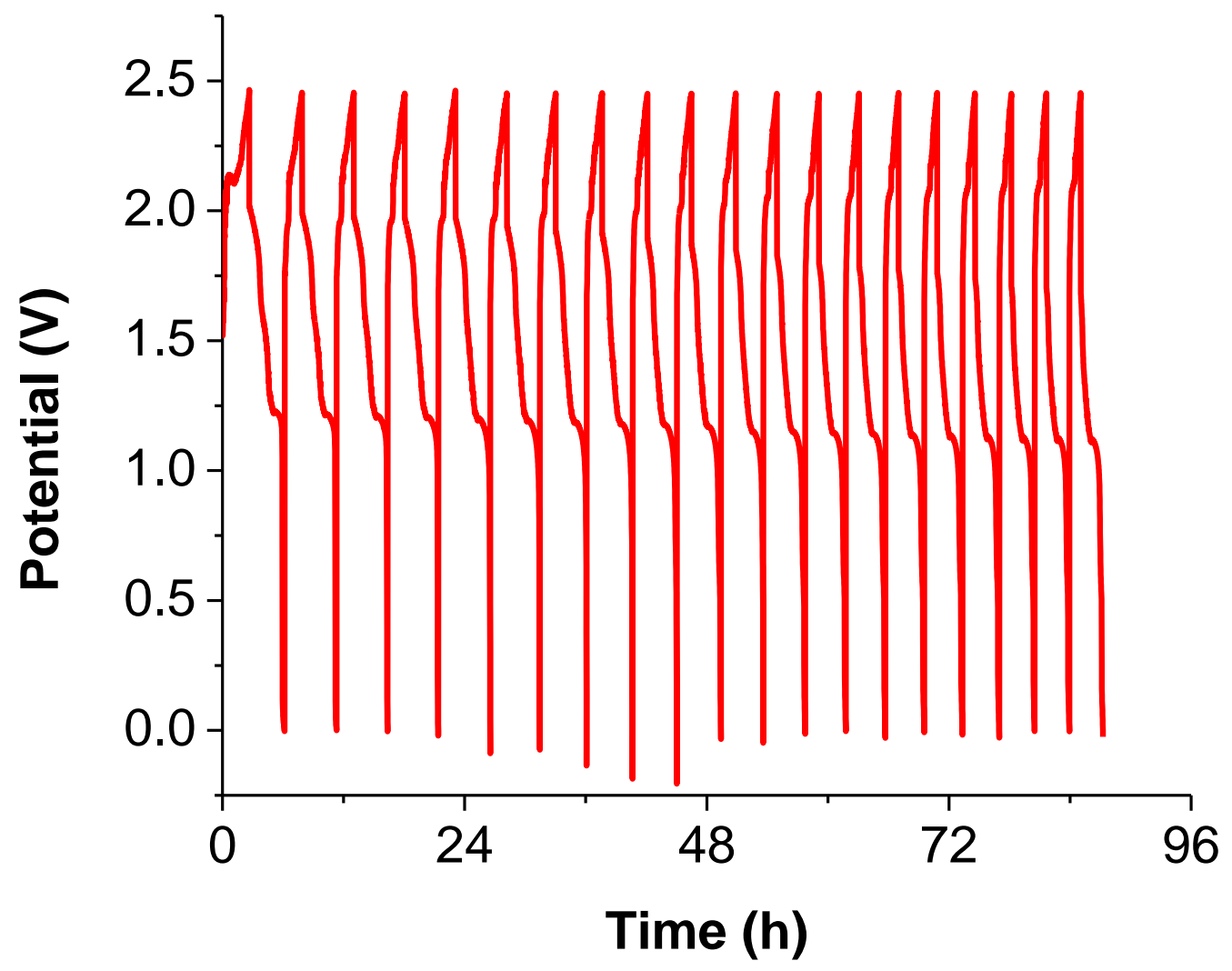

Figure S15. Galvanostatic, two-electrode charge-discharge curves of a slurry of $\mathbf{1}$. Taken in a glass-fritted $\mathrm{H}$-cell with $\mathrm{CH}_{3} \mathrm{CN}, 0.2 \mathrm{M}\left[\mathrm{Bu}_{4} \mathrm{~N}\right]\left[\mathrm{PF}_{6}\right], 32.1 \mu \mathrm{mol}$ of 1 per compartment, and $5 \mathrm{~mL}$ of solution per side. Coiled Pt working electrode, coiled Pt counter electrode. $500 \mu \mathrm{A}$ charge, -250 $\mu$ A discharge. 


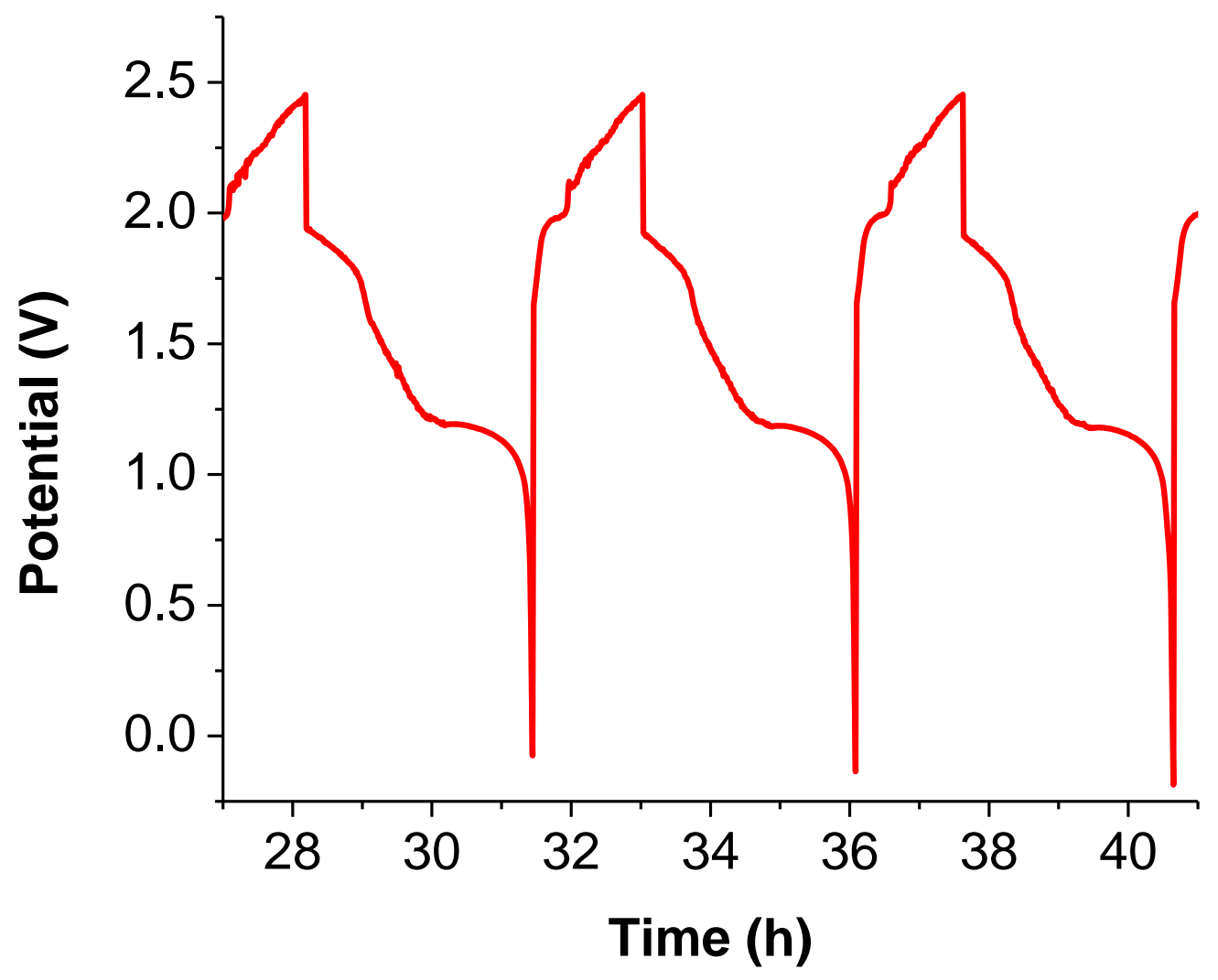

Figure S16. Galvanostatic, two-electrode charge-discharge curves of a slurry of $\mathbf{1}$. Taken in a glass-fritted $\mathrm{H}$-cell with $\mathrm{CH}_{3} \mathrm{CN}, 0.2 \mathrm{M}\left[\mathrm{Bu}_{4} \mathrm{~N}\right]\left[\mathrm{PF}_{6}\right], 32.1 \mu \mathrm{mol}$ of 1 per compartment, and $5 \mathrm{~mL}$ of solution per side. Coiled Pt working electrode, coiled Pt counter electrode. $500 \mu \mathrm{A}$ charge, -250 $\mu$ A discharge. 


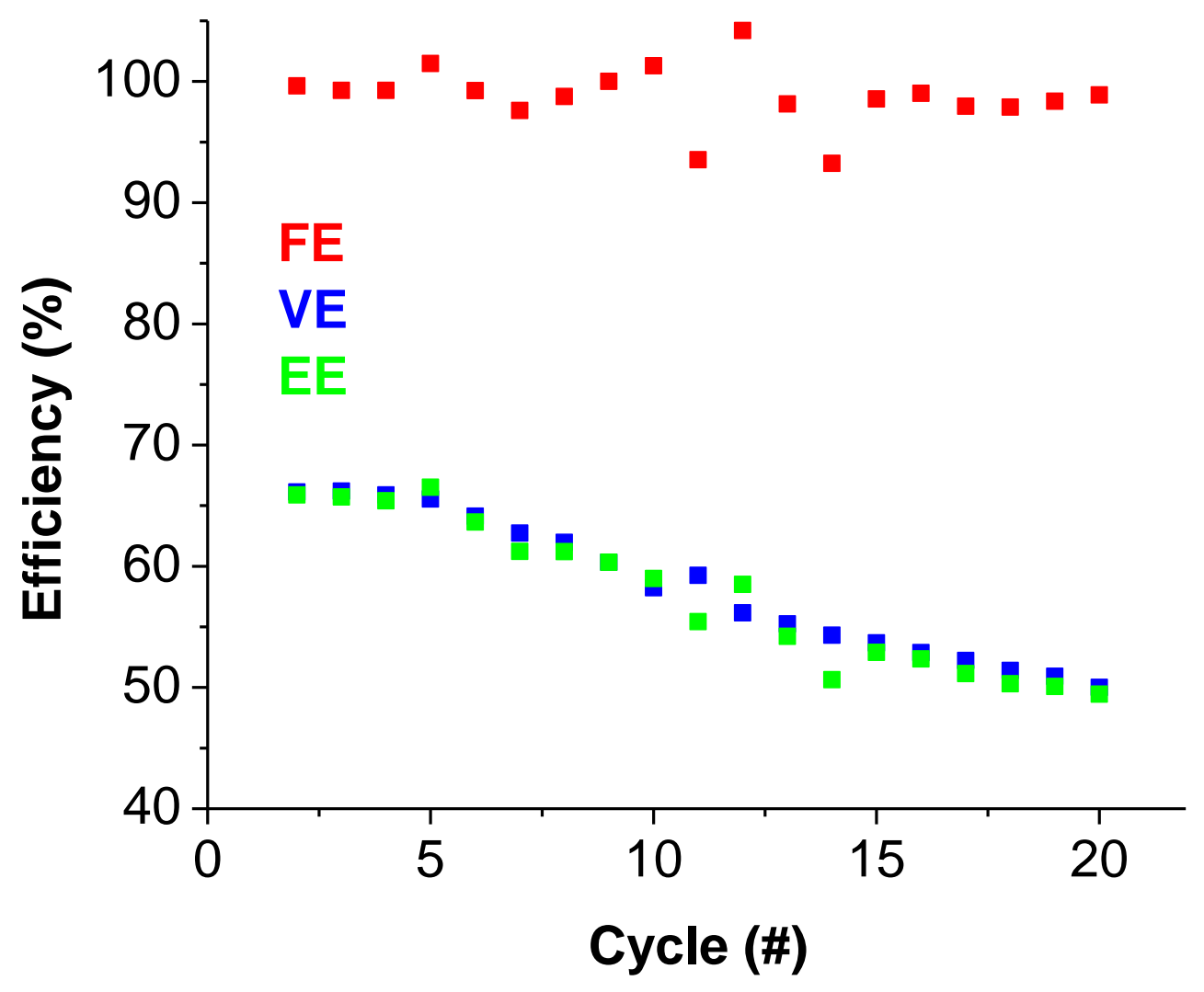

Figure S17. Efficiency values of a slurry of 1 (Faradaic efficiency (FE); Voltage efficiency (VE); Energy efficiency (EE)). Taken in a glass-fritted $\mathrm{H}$-cell with $\mathrm{CH}_{3} \mathrm{CN}, 0.2 \mathrm{M}\left[\mathrm{Bu}_{4} \mathrm{~N}\right]\left[\mathrm{PF}_{6}\right], 32.1$ $\mu \mathrm{mol}$ of 1 per compartment, and $5 \mathrm{~mL}$ of solution per side. Coiled Pt working electrode, coiled Pt counter electrode. $500 \mu \mathrm{A}$ charge, $-250 \mu \mathrm{A}$ discharge. 


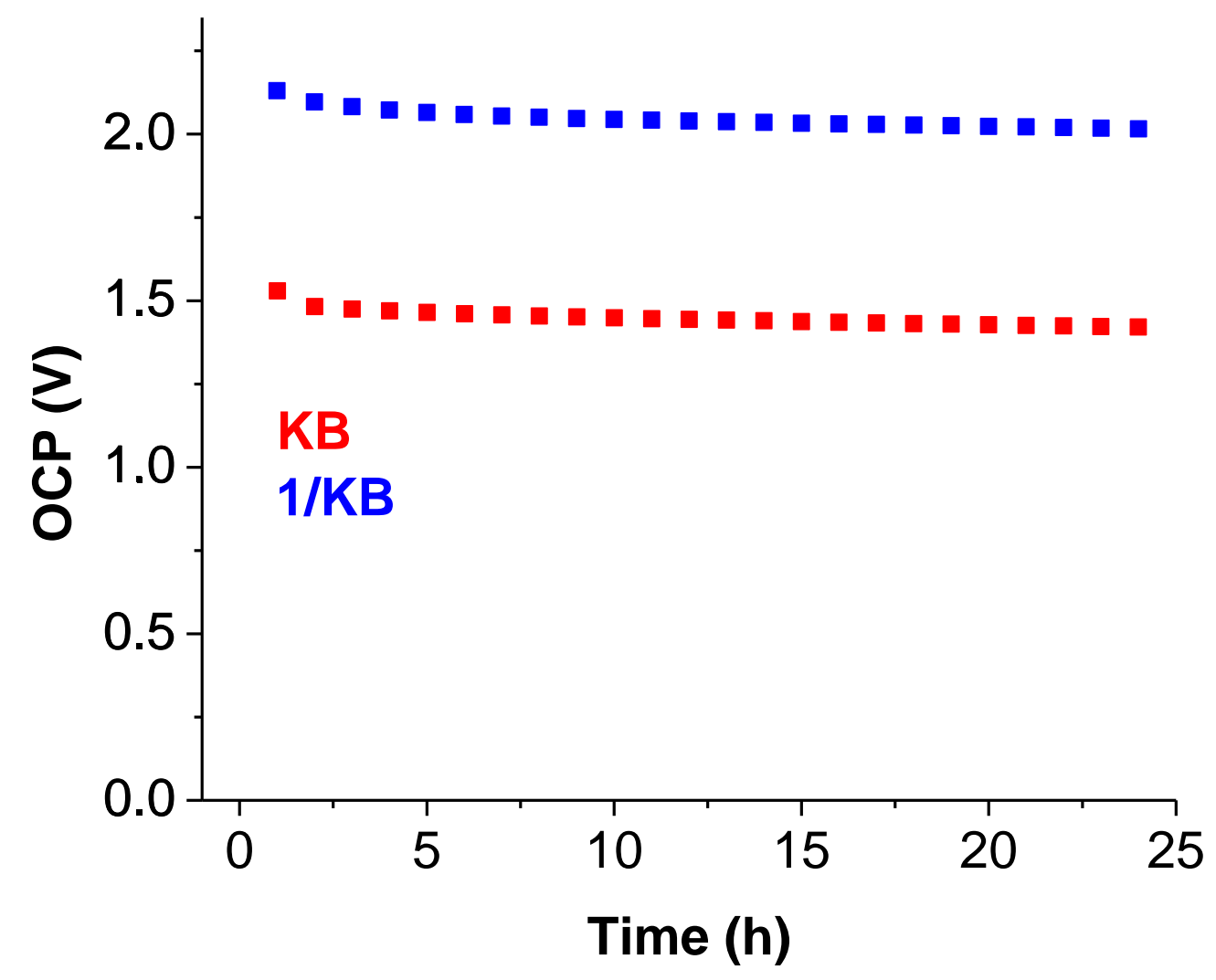

Figure S18. Slurry-state self-discharge experiments for KB (red) and $\mathbf{1} / \mathrm{KB}$ (blue), with the same experimental and charging conditions as done for galvanostatic cycling experiments. Each cell was charged using a voltage cutoff of $2.35 \mathrm{~V}$, and the OCP was monitored over the course of $24 \mathrm{~h}$. 

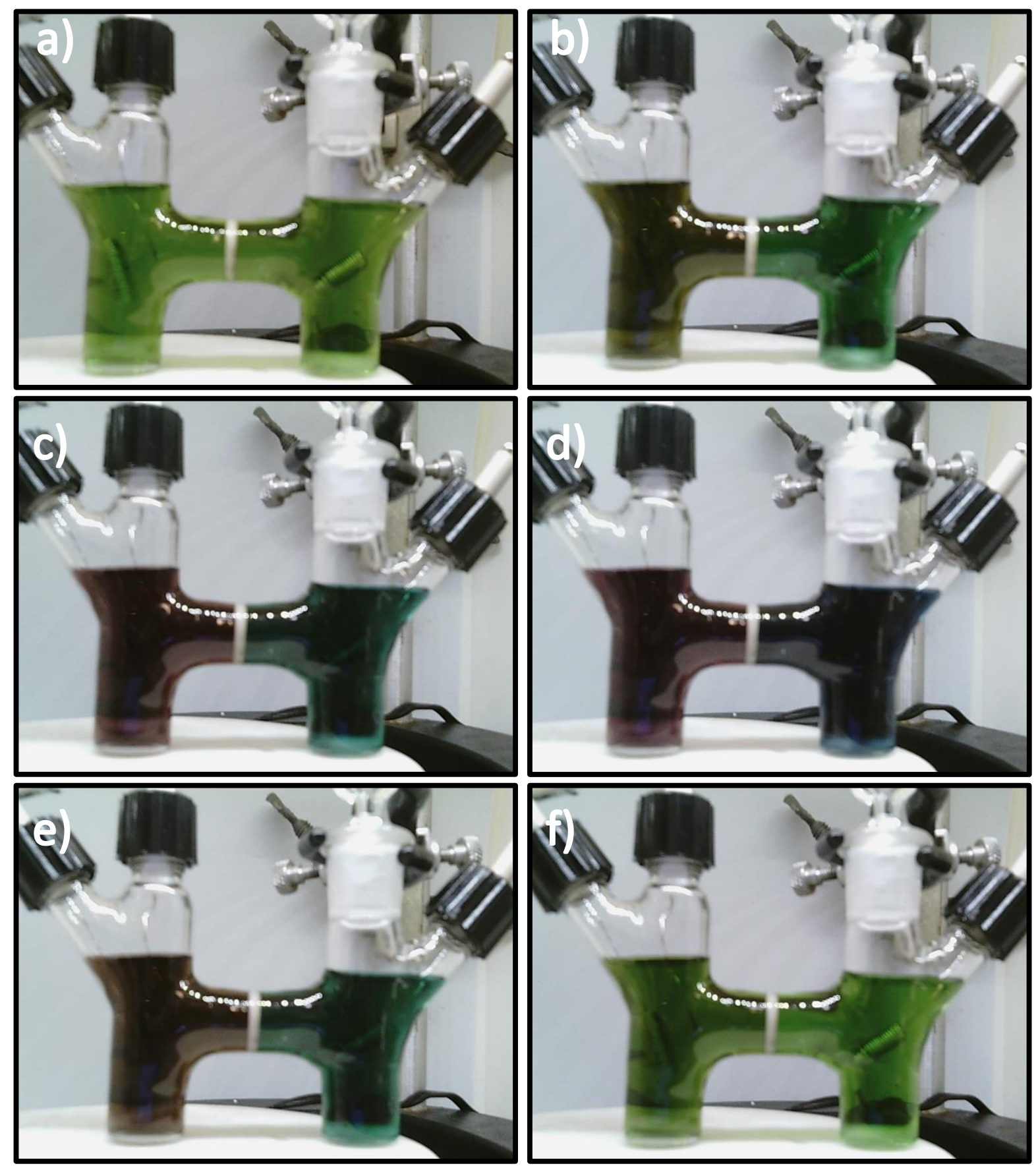

Figure S19. One full charge/discharge cycle of $\mathbf{1}$, in $\mathrm{CH}_{3} \mathrm{CN}$ with oxidation and reduction occurring in the left and right compartment on charging, respectively. (a-d) were taking during charging, and (e-f) were taken during discharging. (a) $=\sim 0 \%$ state of charge (SOC), (b) $=\sim 25 \%$ SOC, (c) $=50 \%$ SOC, (d) $\sim 75 \%$ SOC, (e) $\sim 35 \%$ SOC, (f) $=\sim 0 \%$ SOC. 


\section{S3. Reference}

1. Hunt, C.; Peterson, M.; Anderson, C.; Chang, T.; Wu, G.; Scheiner, S.; Ménard, G. Switchable Aromaticity in an Isostructural Mn Phthalocyanine Series Isolated in Five Separate Redox States. J. Am. Chem. Soc. 2019, 141, 2604-2613.

2. Cabrera, P. J.; Yang, X.; Suttil, J. A.; Hawthorne, K. L.; Brooner, R. E. M.; Sanford, M. S.; Thompson, L. T. Complexes Containing Redox Noninnocent Ligands for Symmetric, Multielectron Transfer Nonaqueous Redox Flow Batteries. J. Phys. Chem. C 2015, 119, 15882-15889. 